\title{
EVALUATION OF ALOE VERA LEAF EXTRACTS AND ALOE EMODIN ON SEVERAL CANCER CELL LINES
}

\author{
NURIYE AKEV ${ }^{1 *}$, EDA CANDOKEN $^{1}$, SERAP ERDEM KURUCA $^{2}$ \\ ${ }^{1}$ Department of Biochemistry, Faculty of Pharmacy, Istanbul University, 34116, Istanbul, Turkey \\ ${ }^{2}$ Department of Physiology, Istanbul Faculty of Medicine, Istanbul University, 34093, Istanbul, Turkey \\ *corresponding author: nakev@istanbul.edu.tr
}

Manuscript received: October 2019

\begin{abstract}
Fresh leaf skin aqueous and methanolic extracts as well as shade-dried leaf skin methanolic extracts prepared separately from the leaves of Aloe vera and aloe emodin (AE) were assayed on human gastric (AGS), colon (HT-29, HCT116) and hepatocellular (HEPG2) cancer cell lines relative to human umbilical vein endothelial cells (HUVEC). AE, 5-fluorouracil (5-FU) and imatinib (IM) were tested as positive controls. Among the four extracts studied, A. vera gel extract (AVG) had the highest cytotoxic effect on cancer cells, with the highest effect on HCT116 cells, while no cytotoxic effect on HUVEC cells was detected. AE has also selective cytotoxic and apoptotic effects on the cancer cells and was ineffective on normal cells. AVG treatment in HCT116 cells induced the apoptosis by the activation of caspase- 9 and caspase- 3 . According to our results, AVG and AE could be proposed as promising cytotoxic drugs from natural origin.
\end{abstract}

\section{Rezumat}

Extractele apoase și metanolice ale frunzelor proaspete, precum și extractele metanolice ale frunzelor uscate de Aloe vera și aloe emodin (AE) au fost analizate pe linii celulare canceroase gastrice (AGS), de colon (HT-29, HCT116) şi hepatocelulare (HEPG2) față de celulele endoteliale ale venei ombilicale umane (HUVEC). AE, 5-fluorouracil (5-FU) și imatinib (IM) au fost martori pozitivi. Dintre cele patru extracte studiate, extractul de A. vera gel (AVG) a prezentat efect citotoxic superior asupra celulelor canceroase, în special asupra celulelor HCT116, și nici un efect citotoxic asupra celulelor HUVEC. AE are, de asemenea, efecte selective citotoxice şi apoptotice asupra celulelor canceroase. Tratamentul cu AVG asupra celulelelor HCT116 a indus apoptoza prin activarea caspazei-9 și a caspazei-3. În concluzie, AVG și AE prezintă potenţial chimioterapic promițător pentru terapia cancerului.

Keywords: AGS, aloe emodin, Aloe vera, annexin V, caspase, HCT116, HEPG2, HT-29, HUVEC, MTT

\section{Introduction}

As it is known, conventional chemotherapeutic drugs have deleterious side effects, by killing normal cells along with cancer cells. Therefore, plants are widely researched in the hope of finding anti-cancer and cytotoxic compounds [35, 40]. Many studies were conducted on the antitumour effects of Aloe vera since $1981[9,39$, 41]. In our laboratory, $A$. vera leaf skin aqueous extract was proved to be effective as prophylactic against Ehrlich ascites tumours in vivo [4]. Antitumour and cytotoxic potential of $A$. vera extracts continues to be the interest of scientific research until recent years $[6,13,28]$.

The success of $A$. vera in the treatment of multiple diseases has been attributed to the presence of several compounds [3, 8, 13, 34]. The inner gel or pulp has been shown to contain compounds with immunomodulatory activity [16], nevertheless some researchers claim that the synergistic activity of all chemicals contained in the whole leaf extracts could be responsible for the healing properties of the "wonder plant" [15]. Aloe emodin (AE), which is one of the major anthraquinone derivatives of $A$. vera, was reported to have anti-tumour and angiogenic properties [5, 20, 22]. Therefore, in recent years, aloe emodin has been investigated for its cytotoxic and anti-cancer effects in various types of cancer [7, 25, 38].

A. vera has also been proved beneficial for most digestive problems including constipation, colitis, peptic ulcers [19, 34] as well as hepatoprotective [29]. The present study evaluates the cytotoxic effect of different aqueous and methanolic extracts prepared from the plant leaves and Aloe emodin on different gastric and hepatic tumour and normal cell lines.

\section{Materials and Methods}

Cell lines and cell culture Human gastric (AGS), colon (HT-29 and HCT116), hepatocellular (HEPG2) tumour cell lines and human umbilical vein endothelial cells (HUVEC) were purchased from American Type Culture Collection (ATCC, Manassas, VA). The cells were cultured in DMEM (Dulbecco's Modified Eagle's medium; Sigma-Aldrich) supplemented with $10 \%$ foetal bovine serum (FBS; Capricorn FBS-12A), 100 units/mL penicillin and 
FARMACIA, 2020, Vol. 68, 6

$100 \mu \mathrm{g} / \mathrm{mL}$ of streptomycin (Gibco 15140-122), in a humidified incubator containing $5 \% \mathrm{CO}_{2}$ at $37^{\circ} \mathrm{C}$. In order to reach the sufficient cell number for tests, cells were passaged after reaching $80 \%$ monolayer confluency. Cells were harvested gently by $0.25 \%$ trypsin (Merck)/ EDTA (Chem Cruz) solution. Cells were sub-cultured every 2 or 3 days.

Plant material

Fresh leaves of the A. vera (L.) Burm. f. (Aloaceae; Xanthoraceae) plant which was cultivated in the Greenhouse of Istanbul University Alfred Heilbronn Botanical Garden, Turkey, were used in the study. A voucher specimen was deposited in the Herbarium of the Faculty of Pharmacy, ISTE No. 65118.

Preparation of extracts

Four types of extract were prepared separately: A. vera fresh leaf skin aqueous extract, $A$. vera gel extract (AVG), A. vera fresh leaf skin methanolic extract and "A. vera dried leaf skin methanolic extract".

Preparation of fresh leaves skin aqueous extract and gel extracts

A. vera fresh leaves were washed carefully with water and dried with filter paper (Whatmann 41). Then the leaves were longitudinally split in two, the gel (198.74 g) was separated by scraping and homogenized in a Waring blender. The gel was filtered through cloth and then filtrate was centrifuged at $4^{\circ} \mathrm{C}, 10,000 \mathrm{rpm}$, for $30 \mathrm{~min}$. The supernatant was lyophilised (4.63 $\mathrm{g}$ ) and considered to be AVG. The remaining leaves (leaf skins $171 \mathrm{~g}$ ) were cut in small pieces, homogenized in a Waring blender with $855 \mathrm{~mL}$ distilled water, filtered through cloth and then the filtrate was centrifuged (Thermo) at $4^{\circ} \mathrm{C}, 12,000 \mathrm{rpm}, 15 \mathrm{~min}$. The supernatant was lyophilised (11.57 g) and considered to be " $A$. vera fresh leaf skin aqueous extract".

Preparation of fresh leaves skin and dried leaf skin methanolic extracts

Fresh leaf skins ( $33.67 \mathrm{~g}$ ) were dried in ventilated oven at $60^{\circ} \mathrm{C}, 2$ hours. The dried leaf skins were powdered and stored at room temperature in the dark until extraction. The obtained dried leaf skin $(4.25 \mathrm{~g})$ and fresh leaf skin $(73.4 \mathrm{~g})$ were extracted using Soxhlet extractor with methanol for 3 days. After extraction and filtration through paper, $260 \mathrm{~mL}$ of fresh leaves filtrate and $143 \mathrm{~mL}$ of dried leaves filtrate were obtained. The methanol solvent was evaporated for $30 \mathrm{~min}$ in a rotary evaporator, giving rise to a semi solid crude extract (3.32 g) named A. vera fresh leaf skin methanolic extract. The same procedure was performed after drying leaf skins at $60^{\circ} \mathrm{C}$ for 2 hours in an oven and considered to be $(1.17 \mathrm{~g})$ "A. vera dried leaf skin methanolic extract". These four different extracts prepared as described above were conserved at $-20^{\circ} \mathrm{C}$ until further use.

Preparation of test materials and reference drugs

Aloe emodin (AE; 1,8-dihydroxy-3-[hydroximethyl]anthraquinone) was purchased from Sigma-Aldrich (St Louis, MO, cat no. A7687). A. vera extracts (10 $\mathrm{mg} / \mathrm{mL})$ and $\mathrm{AE}(20 \mathrm{mM})$ stock solutions were prepared in dimethyl sulfoxide (DMSO was purchased from Sigma-Aldrich D2650). The reference chemotherapeutic drugs, 5-fluorouracil (5-FU; $50 \mathrm{mg} / \mathrm{mL}$ in physiological water, ready for use, kind present of Clinical Oncology Department, Istanbul Faculty of Medicine, Istanbul University), and imatinib (purchased from Santa Cruz) $10 \mathrm{mM}$ stock solution was prepared in DMSO; All solutions were stored at $-20^{\circ} \mathrm{C}$ and diluted with medium when used.

\section{Trypan blue exclusion assay}

The total number of viable cells was determined at each time point by the trypan blue exclusion test [37]. Exactly $10 \mu \mathrm{l}$ of cell suspensions were stained with an equal volume of trypan blue $(0.4 \%$ in $10 \mathrm{mM}$ in phosphate buffer saline (PBS)) for $1 \mathrm{~min}$. Then the numbers of viable cells were counted with Neubauer Chamber by light microscopy (Olympus). Cells that retained a blue colour were considered as dead cells. MTT colorimetric assay

The 3-(4,5-dimethylthiazol-2-yl)-2,5-diphenyltetrazolium bromide (MTT) colorimetric assay was used to screen for cytotoxic activity [27]. For this purpose 96-well plates were used and the assay was done in a total volume of $100 \mu \mathrm{L}$. Briefly, $10 \mu \mathrm{L} /$ well of varying concentrations of $A$. vera extracts and $\mathrm{AE}$ (1.25 - 200 $\mu \mathrm{M}), \mathrm{IM}(0.1$ - $50 \mu \mathrm{M})$, and 5-FU $(0.15-5 \mathrm{mg} / \mathrm{mL})$, as positive controls were added and subsequently the cells ( $90 \mu \mathrm{L} /$ well; $10^{5}$ cells $/ \mathrm{mL}$ culture medium) were seeded to treat for $72 \mathrm{~h}$. In addition, $90 \mu \mathrm{L}$ cell suspension and $10 \mu \mathrm{L}$ medium were added to control wells. The supernatant was aspirated (50 $\mu \mathrm{L} /$ well), subsequently the cells were treated with MTT (SigmaAldrich) solution ( $10 \mu \mathrm{L}$ of $5 \mathrm{mg} / \mathrm{mL}$ PBS $)$ at $37^{\circ} \mathrm{C}$ for 3 h. Finally, cells were lyzed with $100 \mu \mathrm{L}$ DMSO. Absorbance was measured at $570 \mathrm{~nm}$ using a ELISA microplate reader (Rayto RT-2100C). The percentage of viable cells (VI) determined with the equation (1):

$\mathrm{VI}=($ Absorbance of the treated cells/Absorbance of the control cells) $\times 100$ (1)

The $\mathrm{IC}_{50}$ which is the amount of sample that provides $50 \%$ inhibition of cell growth was calculated from a dose-response curve. The cytotoxic effect of $A$. vera extracts and controls were evaluated by comparing the $\mathrm{IC}_{50}$ values of the samples for all cell lines.

Flow cytometry analysis

Annexin V-FITC/propidium iodide (PI) assay kit (Millipore) was used to distinguish normal, apoptotic, and necrotic cells. For this purpose a 6-well plate was used and the assay was done in a total volume of $2 \mathrm{~mL}$. The three groups of cells (two untreated control cells group: to apply and unapplied Annexin V-FITC/PI for one test group; $1800 \mu \mathrm{L} /$ well; $10^{5}$ cells $/ \mathrm{mL}$ culture medium) were seeded in a final concentration of $\mathrm{IC}_{50}$ (200 $\mu \mathrm{L} /$ well) of $A V G$ and AE. Subsequent to culture at $37^{\circ} \mathrm{C}$ with $5 \% \mathrm{CO}_{2}$ for $72 \mathrm{~h}$, the cells were harvested by trypsinization. Trypsinized and loose cells were then combined and pelleted by centrifuging at $2000 \mathrm{rpm}$ 
for $10 \mathrm{~min}$. The pellets were resuspended and washed with PBS, then resuspended in $100 \mu \mathrm{L}$ of Annexin Binding Buffer (4X) and stained with $3 \mu \mathrm{L}$ Annexin V-FITC, $2 \mu \mathrm{L}$ PI. The cell suspension was incubated for $45 \mathrm{~min}$ at room temperature in the dark. The cell suspension was then immediately analysed by flow cytometry. Cell Quest software was used to analyse $10^{4}$ cells. Acquisition of samples were determined with a FACS Calibur flow cytometer and analysed with CELLQUEST software (BD Biosciences).

Western Blot Analysis

For apoptic protein expression analysis, cells $(45 \mathrm{~mL}$; $10^{5}$ cells/mL culture medium) were seeded in $75 \mathrm{~cm}^{2}$ cell culture treated flasks. After 12, 24 and $72 \mathrm{~h}$ of the $A$. vera gel treatment, cells were harvested and pelleted. Pellets washed with PBS, then resuspended in $100 \mu \mathrm{L}$ lysis buffer ( $1 \mathrm{mM}$ EDTA, $10 \mathrm{mM}$ TrisHCL, $0.5 \%$ Triton X-100, pH 8) with addition (1:1000) of $100 \mathrm{nM}$ phenylmethylsulfonyl fluoride (PMSF) followed by incubation on ice for $60 \mathrm{~min}$ by vortexing every $10 \mathrm{~min}$. The cell lysate was centrifuged at 14,000 rpm for $10 \mathrm{~min}$ and the supernatant was collected as total protein extract. The protein concentration was detected using the Bradford method. All the samples were mixed with Laemli sample buffer (2X) (Biorad), then transferred to a $80^{\circ} \mathrm{C}$ water bath for $15 \mathrm{~min}$ and stored at $-80^{\circ} \mathrm{C}$ for later use. $10-20 \mu \mathrm{g}$ of protein was separated on $15 \%$ SDS-PAGE gel performed at 200 $\mathrm{mA}$. PVDF blotting membranes ( 0.45 micron), activated in methanol for a few seconds, after electrophoresis. Blotting were performed overnight at $40 \mathrm{~mA}$ at $4^{\circ} \mathrm{C}$ using Towbin reagent, Wet/Tank Blotting Systems, BIORAD. The membranes were blocked with $5 \%$ skimmed milk powder in TBS (Sigma) containing 0.05\% Tween-20 (Santa Cruz Biotech., Dallas, Texas, USA) for $1 \mathrm{~h}$, at RT and then incubated with primary antibodies overnight at $4^{\circ} \mathrm{C}$ on a shaker at low speed. Antibodies directed against the following proteins were used in this study: actin (1:1000, Santa Cruz Biotech., sc-1616, goat polyclonal IgG), caspase-3 (1:200, Santa Cruz Biotechnology, sc-7148, rabbit polyclonal IgG), caspase-9 (1:200, Santa Cruz Biotech., sc-7885, rabbit polyclonal IgG). The secondary antibodies were used goat anti-rabbit IgG-HRP (HRP: Horseradish Peroxidase, Santa Cruz Biotech., sc-2030) for caspase-3 and caspase-9. The fluorescent bands were visualized with KETA Wealtec Chemiluminescence Imaging System with Magic-Chemi software and Novex ${ }^{\circledR}$ AP Chromogenic Substrate (BCIP/NBT, cat no. WP20001, invitrogen).

Statistical analysis. The results were statistically analysed using the independent Student's t-test. Data were represented as means \pm standard deviation (S.D.) and at least in triplicate. Results were considered significant for $\mathrm{p}<0.05$.

\section{Results and Discussion}

Cytotoxic Activity

The results of cytotoxicity studies are summarized in Table I.

IC 50 values of different $A$, vera leaf extracts and reference drugs on cell lines

\begin{tabular}{|l|c|c|c|c|c|c|c|}
\hline Cell line & \multicolumn{9}{|c|}{ IC } & $\begin{array}{c}\text { Fresh leaf skin } \\
\text { aqueous extract } \\
(\boldsymbol{\mu g} / \mathbf{m L})\end{array}$ & $\begin{array}{c}\text { AVG } \\
(\boldsymbol{\mu g} / \mathbf{m L})\end{array}$ & $\begin{array}{c}\text { Fresh leaf skin } \\
\text { methanolic extract } \\
(\boldsymbol{\mu g} / \mathbf{m L})\end{array}$ & $\begin{array}{c}\text { Dried leaf skin } \\
\text { methanolic extract } \\
(\boldsymbol{\mu g} / \mathbf{m L})\end{array}$ & $\begin{array}{c}\text { AE } \\
(\boldsymbol{\mu M})\end{array}$ & $\begin{array}{c}\text { IM } \\
(\boldsymbol{\mu M})\end{array}$ & $\begin{array}{c}\mathbf{5 - F U} \\
(\mathbf{m g} / \mathbf{m L})\end{array}$ \\
\hline AGS & $493.11 \pm 143.43$ & $528.07 \pm 88.46$ & $443.55 \pm 51.18$ & $427.06 \pm 40.69$ & $19.03 \pm 0.25$ & $65 \pm 1.31$ & $>5$ \\
\hline HT-29 & $1803.97 \pm 1.80$ & $334.18 \pm 2.67$ & $1026.72 \pm 1.13$ & $3204.85 \pm 15.07$ & $>100$ & $56 \pm 1.37$ & $>5$ \\
\hline HCT116 & $275.77 \pm 26.03$ & $206.88 \pm 6.03$ & $241.33 \pm 26.02$ & $292.42 \pm 35.11$ & $>150$ & $50 \pm 2.60$ & $0.40 \pm 0.03$ \\
\hline HEPG2 & $967.62 \pm 247.42$ & $697.14 \pm 154.71$ & $602.52 \pm 131.28$ & $595.17 \pm 380.65$ & $166.97 \pm 5.41$ & $106 \pm 3.40$ & $0.47 \pm 0.02$ \\
\hline HUVEC & $1445.09 \pm 35.37$ & $927.79 \pm 57.22$ & $868.87 \pm 44.82$ & $574.12 \pm 20.69$ & $>100$ & $25 \pm 1.65$ & $>5$ \\
\hline
\end{tabular}

$* \mathrm{IC}_{50}$ is the effective concentration for which the cell alive was $50 \%$ and was obtained from dose response curve.

Data are presented as the mean of three replicates \pm standard deviation.

\section{Effect of A. vera extracts and reference drugs on AGS} cells

The cytotoxic effects of $A$. vera extracts $(62.5,125$ and $250 \mu \mathrm{g} / \mathrm{mL}$ ) on AGS cells given as percentage of viable cells are shown in Figure 1A. The cytotoxic efficacy was as follows: $A$. vera dried leaf skin methanolic extract $>A$. vera fresh leaf skin methanolic extract $>A$. vera fresh leaf skin aqueous extract $>$ AVG. The cytotoxic effects of AE on AGS cells given as percentage of viable cells are shown in Figure 1B. The best result was obtained at $80 \mu \mathrm{M}$ AE concentration. Whereas low cytotoxic effects were observed for IM (Figure 1C) and 5-FU (Figure 1D) on AGS cells.
Effect of $A$. vera extracts and reference drugs on HT-29 cells

The cytotoxic effects of $A$. vera extracts $(62.5,125$ and $250 \mu \mathrm{g} / \mathrm{mL}$ ) on HT-29 cells given as percentage of viable cells are shown in Figure 2A. The cytotoxic efficacy was as follows: AVG $>A$. vera fresh leaf skin aqueous extract $>A$. vera fresh leaf skin methanolic extract $=A$. vera dried leaf skin methanolic extract. No cytotoxic effect was observed for $\mathrm{AE}$ (Figure 2B) and 5-FU (Figure 2D). The best result was obtained at $50 \mu \mathrm{M}$ IM concentration. on HT-29 cells (Figure 2C). 
FARMACIA, 2020, Vol. 68, 6

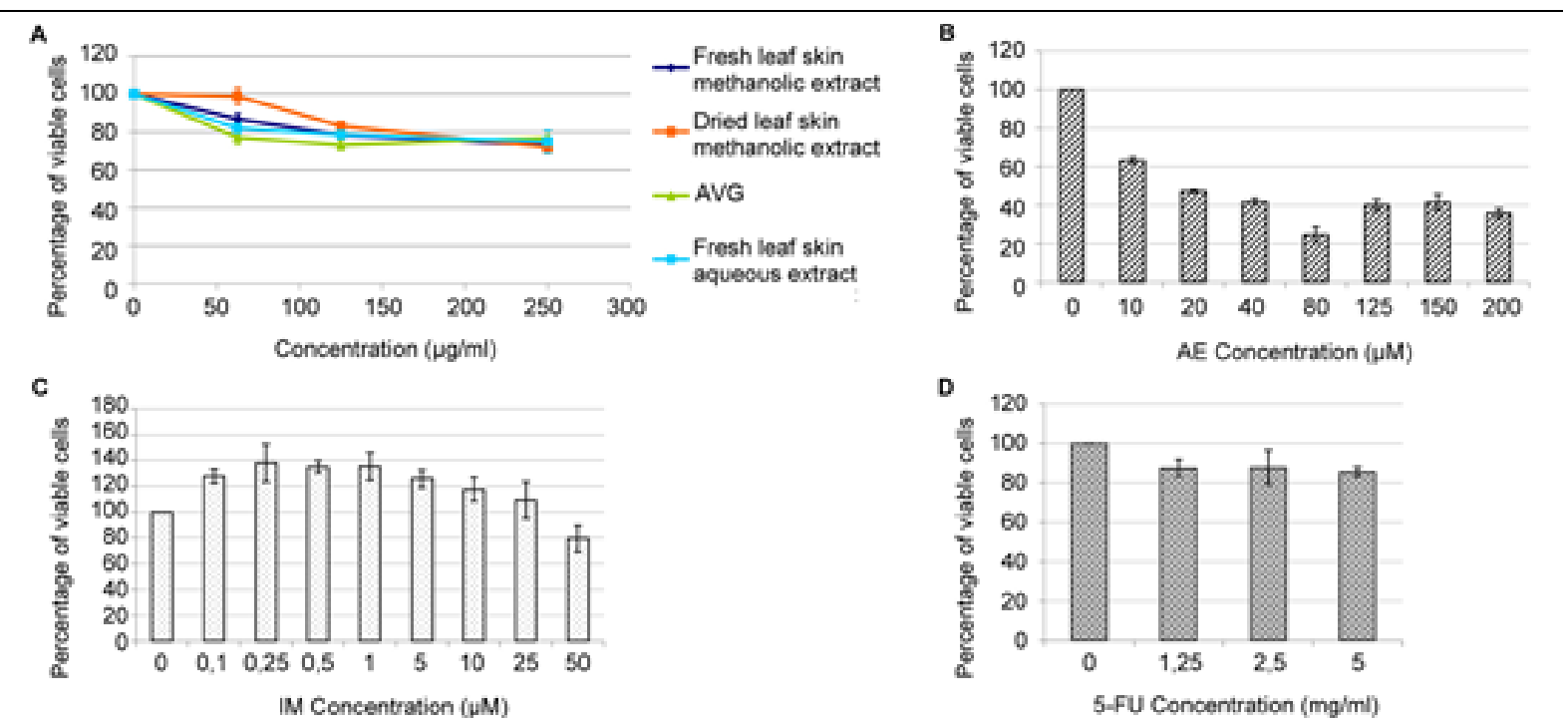

Figure 1.

The cytotoxic effects of A. vera extracts (A), Aloe emodin (B), imatinib (C) and 5-fluorourasil (D) on AGS cell line
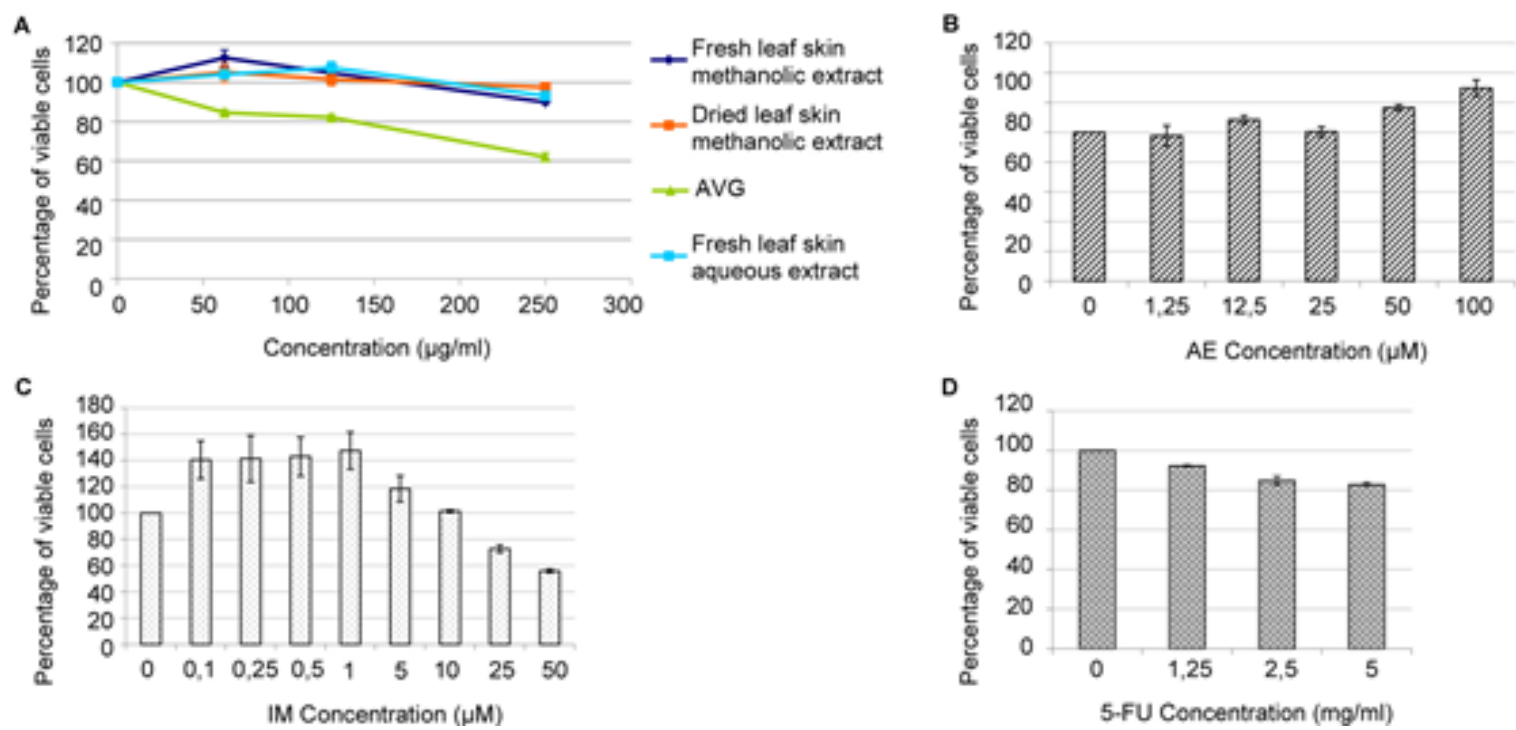

Figure 2.

The cytotoxic effects of A. vera extracts (A), Aloe emodin (B), imatinib (C) and 5-fluorourasil (D) on HT-29 cell line

Effect of A. vera extracts and reference drugs on HCT116 cells

The cytotoxic effects of $A$. vera extracts $(62.5,125$ and $250 \mu \mathrm{g} / \mathrm{ml}$ ) on HCT116 cells given as percentage of viable cells are shown in Figure 3A. The cytotoxic efficacy was as follows: $\mathrm{AVG}>A$. vera fresh leaf skin methanolic extract $>A$. vera fresh leaf skin aqueous extract $>A$. vera dried leaf skin methanolic extract. The cytotoxic effects of AE on HCT116 cells given as percentage of viable cells are shown in Figure 3B. The best result was obtained at $150 \mu \mathrm{M} \mathrm{AE}$ concentration. The best cytotoxic effect of IM (Figure 3C) was found at $50 \mu \mathrm{M}$ and of $5-\mathrm{FU}$ (Figure 3D) at $0.5 \mathrm{mg} / \mathrm{mL}$ concentration on HCT116 cells.
Effect of A. vera extracts and reference drugs on HEPG2 cells

The cytotoxic effects of $A$. vera extracts $(62.5,125$ and $250 \mu \mathrm{g} / \mathrm{mL}$ ) on HEPG2 cells given as percentage of viable cells are shown in Figure 4A. The cytotoxic efficacy was as follows: $\mathrm{AVG}>A$. vera dried leaf skin methanolic extract $>A$. vera fresh leaf skin methanolic extract $>A$. vera fresh leaf skin aqueous extract. The cytotoxic effects of AE on HEPG2 are shown in Figure 4B. The best result was obtained at $200 \mu \mathrm{M}$ $\mathrm{AE}$ concentration. The best cytotoxic effect of IM (Figure 4C) was found at $100 \mu \mathrm{M}$ and of 5-FU (Figure 4D) at $0.5 \mathrm{mg} / \mathrm{mL}$ concentration on HEPG2 cells. 
FARMACIA, 2020, Vol. 68, 6
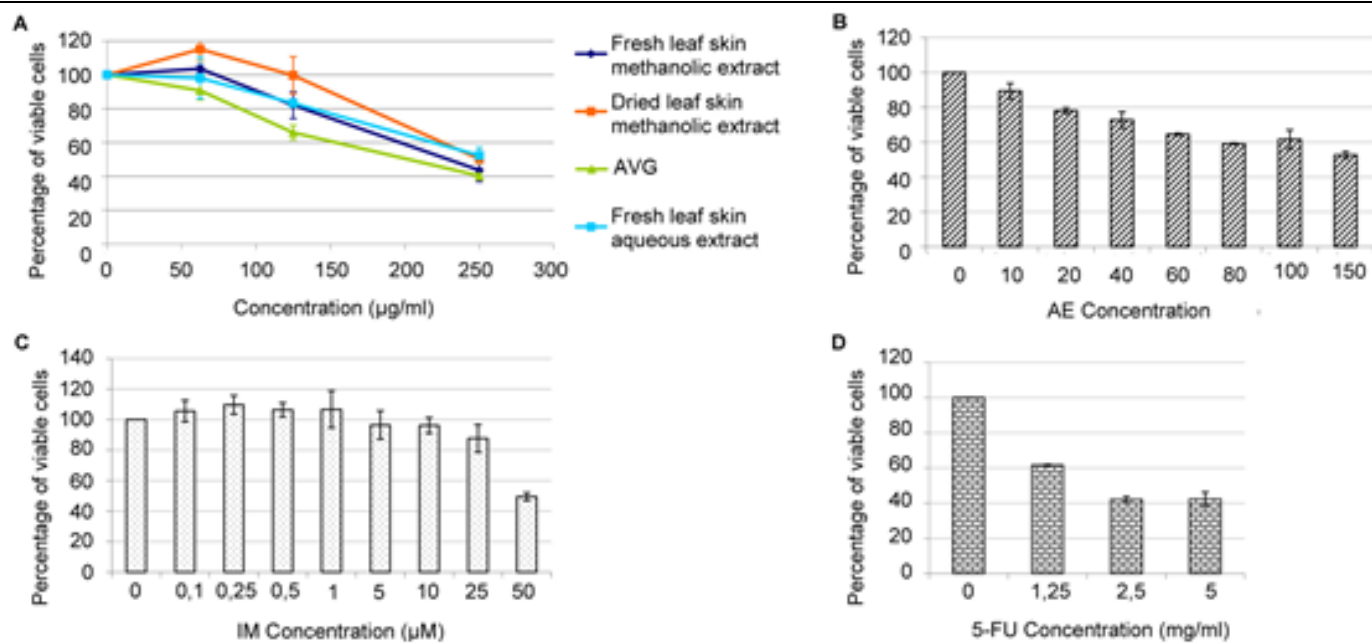

Figure 3.

The cytotoxic effects of $A$. vera extracts (A), Aloe emodin (B), imatinib (C) and 5-fluorourasil (D) on HCT116 cell line
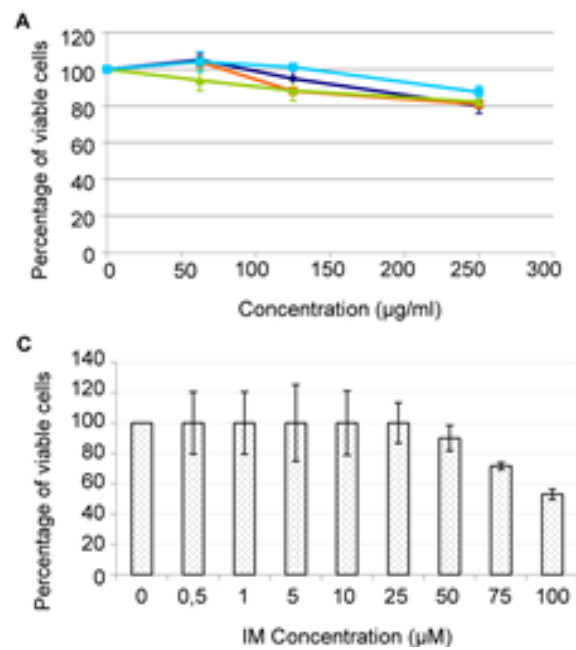
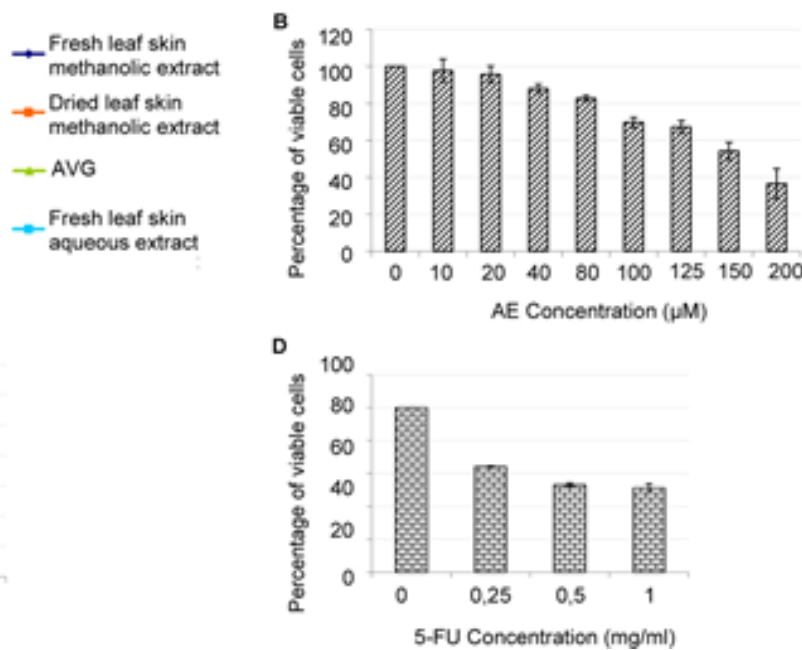

Figure 4.

The cytotoxic effects of A. vera extracts (A), Aloe emodin (B), imatinib (C) and 5-fluorourasil (D) on HEPG2 cell line

Effect of A. vera extracts and reference drugs on HUVEC cells

The cytotoxic effects of $A$. vera extracts $(62.5,125$ and $250 \mu \mathrm{g} / \mathrm{mL}$ ) on HUVEC cells given as percentage of viable cells are shown in Figure 5A. It could be sad that the extracts did not show cytotoxic effect on normal cells. The negligible cytotoxic efficacy was as follows: $A$. vera dried leaf skin methanolic extract $>A$. vera fresh leaf skin methanolic extract $>\mathrm{AVG}>A$. vera fresh leaf skin aqueous extract. AE did not show cytotoxic effects on HUVEC cells (Figure 5B). The best cytotoxic effect of IM was found at $50 \mu \mathrm{M}$ (Figure 5C) and at 1.25 $\mathrm{mg} / \mathrm{mL}$ for 5 -FU (Figure 5D) on HUVEC cells.

Annexin-V/PI apoptosis assay

Annexin-V-FITC/PI double-staining assay was used to evaluate the percentage of apoptotic and necrotic cells in order to confirm that the cytotoxic effect on AGS, HT-29, HCT116 and HEPG2 cells, with their own $\mathrm{IC}_{50}$ doses of $\mathrm{AE}$ and $250 \mu \mathrm{g} / \mathrm{mL} \mathrm{AVG}$ for $72 \mathrm{~h}$, was associated with apoptosis (Table II).

Table II

Rates of apoptosis (\%) and necrosis (\%) in cells

\begin{tabular}{|l|c|c|c|c|}
\hline & \multicolumn{4}{|c|}{ Apoptosis (\%) / Necrosis (\%) } \\
\hline Cells & AGS & HT-29 & HCT116 & HEPG2 \\
\hline AE & $26.11 / 0$ & $0.81 / 0.05$ & $15.46 / 3.07$ & $31.53 / 4.5$ \\
\hline AVG & $0.17 / 0.22$ & $0.53 / 0.09$ & $12.41 / 0$ & $1.51 / 0$ \\
\hline
\end{tabular}

Cells were treated with their own $\mathrm{IC}_{50}$ doses of AE and $250 \mu \mathrm{g} / \mathrm{mL}$ AVG for $72 \mathrm{~h}$, stained with FITC-annexin V/PI and analysed by FACScan flow cytometer marked for apoptosis/necrosis. Apoptosis induction was monitored by flow cytometry using the Annexin VFITC/PI kit. Apoptosis values (apoptosis \%) were considered as the total values of gate percentages of early and late apoptosis.

The cells with the most change in apoptotic cell percentage were identified as HCT116 cell. Treatment with the $\mathrm{IC}_{50}$ value of $150 \mu \mathrm{M} \mathrm{AE}$ and $250 \mu \mathrm{g} / \mathrm{mL}$ AVG in HCT116 cell increased the percentage of earlylate apoptotic cells from $11.81 \%-8.43 \%$ to $15.50 \%$ - 
FARMACIA, 2020, Vol. 68, 6

$20.20 \%$ (Figures $8 \mathrm{~A}$ and $8 \mathrm{~B}$ ) and $46.92 \%-29.26 \%$ to $39.81 \%-48.78 \%$ (Figures 8C and 8D) respectively, indicating that $\mathrm{AVG}$ treatment induces apoptosis in HCT116 (Table II). In addition, treatment with the $\mathrm{IC}_{50}$ values of $\mathrm{AE}$ induces apoptosis at the rates of $26.11 \%$ and $31.53 \%$ apoptosis in AGS (Figures 6A and $6 \mathrm{~B}$ ) and HEPG2 cells (Figures 9A and 9B), respectively. Referring to the results in Figure 7, no apoptosis or necrosis was observed in HT-29 cells. Expression of proteins related to apoptotic pathways in AVG treated HCT116 cells

Since AVG showed apoptotic activity in HCT116 cells at the lowest dose of the $\mathrm{IC}_{50}$, we decided to perform western blot analyses in order to reveal the underlying molecular mechanism. After cells were exposed to 200 $\mu \mathrm{g} / \mathrm{mL} \mathrm{AVG}$ for 12,24 and $72 \mathrm{~h}$, the expression of caspase- 3 and caspase- 9 proteins increased compared with the internal actin expression. As shown in Figure 10, while procaspase- 3 expression increased procaspase- 3 proteins were cleaved to the corresponding active forms in the first 12 hours and procaspase- 9 was cleaved in the 24 hours. According to these results we can postulate that the apoptotic effect of $A$. vera gel treatment in HCT116 cells is mediated by a caspase-dependent pathway.

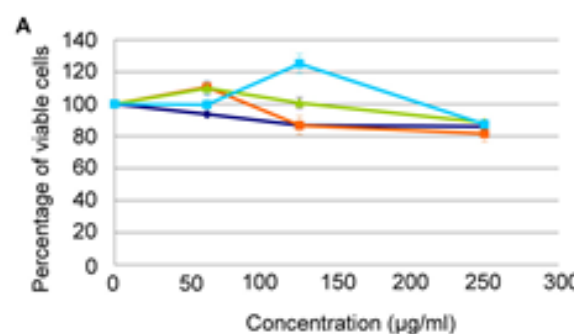

c

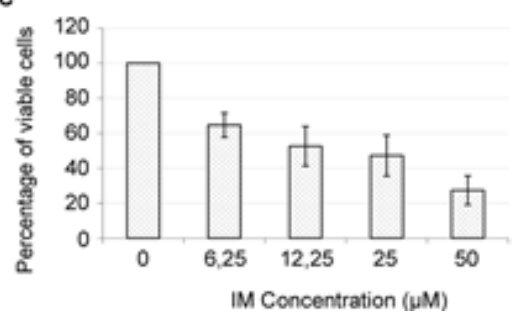

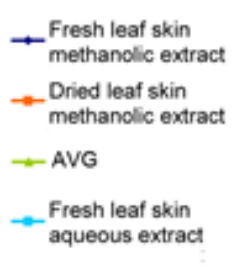
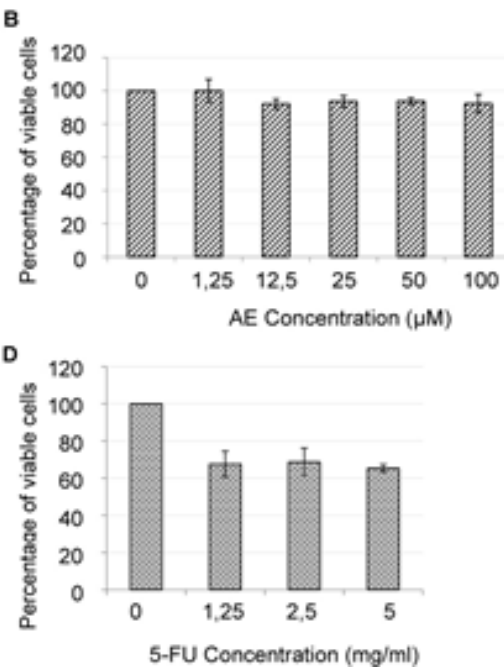

Figure 5.

The cytotoxic effects of $A$. vera extracts (A), Aloe emodin (B), imatinib (C) and 5-fluorourasil (D) on HUVEC cell line

A
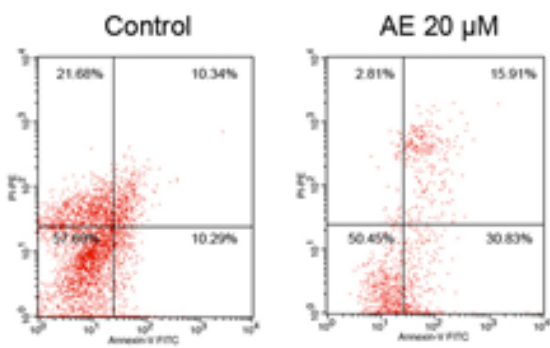

B

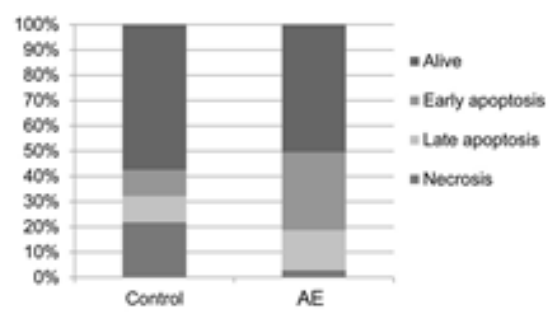

C

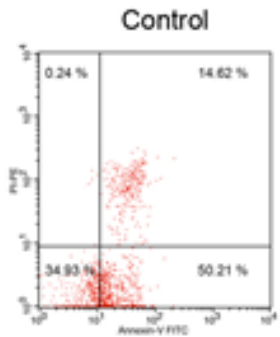

AVG $250 \mu \mathrm{g} / \mathrm{ml}$

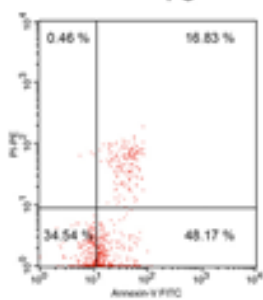

$\mathrm{D}$

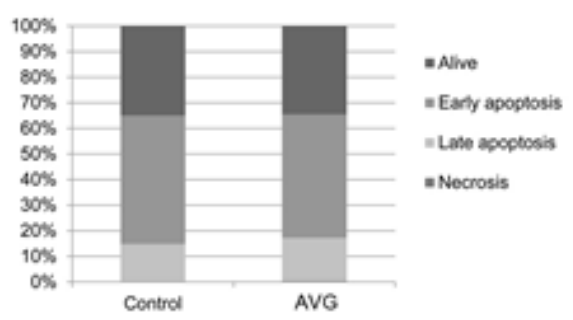

Figure 6.

Flow Cytometry of AGS cells treated with Annexin V-FITC/PI. The cells were maintained with the $\mathrm{IC}_{50}$ value of $20 \mu \mathrm{M}$ AE (A) and $250 \mu \mathrm{g} / \mathrm{mL}$ AVG (C) for $72 \mathrm{~h}$, stained with FITC-annexin V/PI and analysed by FACScan flow cytometer marked for apoptosis/necrosis

Q1: Annexin V negative/PI positive; Q2: Annexin V/PI positive; Q3: Annexin V positive/PI negative; Q4: Annexin V/PI negative. Control cells without the presence of AE and AVG. The analysis of data from flow Cytometry was performed using the FlowJo software. (B, D) Alive \%, early apoptosis \%, late apoptosis and necrosis \% were calculated comparing with treatment and non-treatment groups 

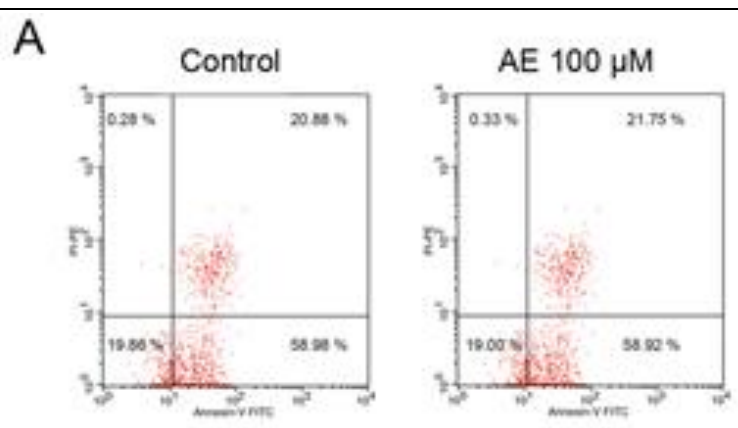

B

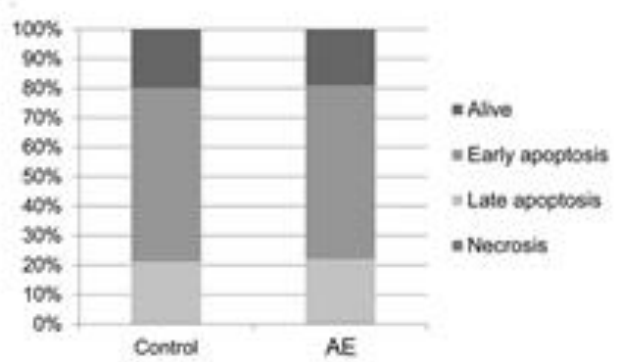

C

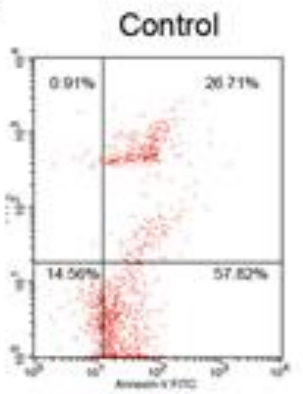

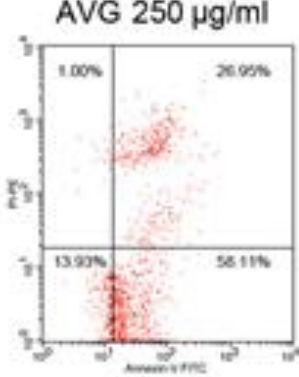

$\mathrm{D}$

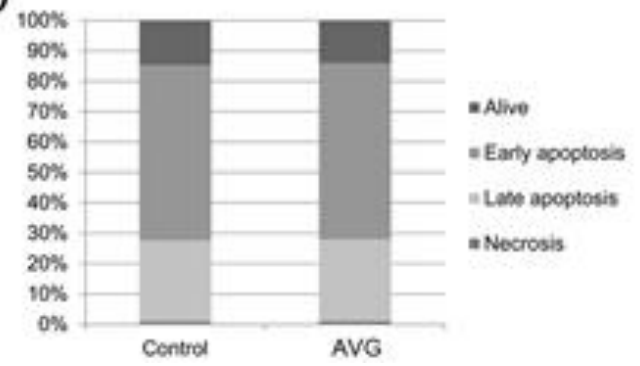

Figure 7.

Flow Cytometry of HT-29 cells treated with Annexin V-FITC/PI. The cells were maintained with the $\mathrm{IC}_{50}$ value of $100 \mu \mathrm{M} \mathrm{AE}$ (A) and $250 \mu \mathrm{g} / \mathrm{mL}$ AVG (C) for $72 \mathrm{~h}$, stained with FITC-annexin V/PI and analysed by FACScan flow cytometer marked for apoptosis/necrosis

Q1: Annexin V negative/PI positive; Q2: Annexin V/PI positive; Q3: Annexin V positive/PI negative; Q4: Annexin V/PI negative. Control cells without the presence of AE and AVG. The analysis of data from flow Cytometry was performed using the FlowJo software. (B, D) Alive \%, early apoptosis \%, late apoptosis and necrosis \% were calculated comparing with treatment and non-treatment groups

A
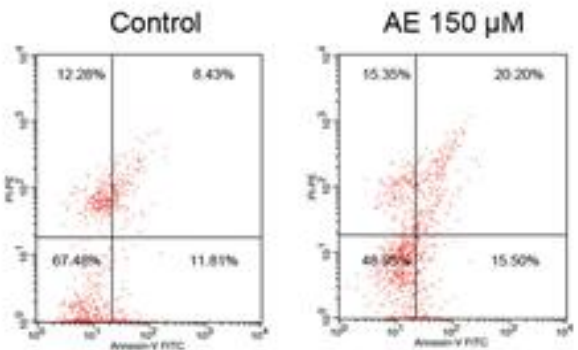

B

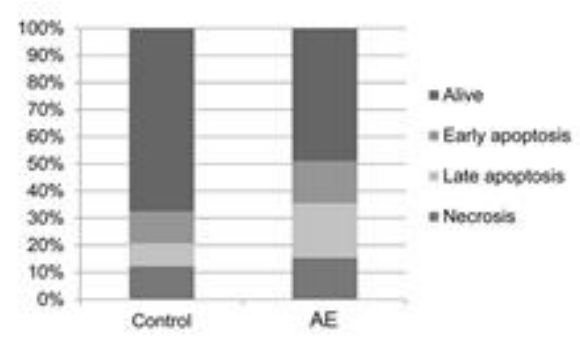

C

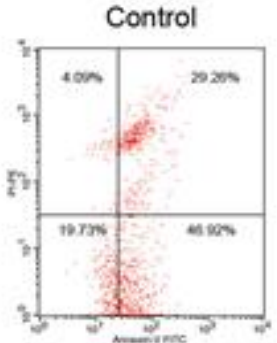
AVG $250 \mu \mathrm{g} / \mathrm{ml}$

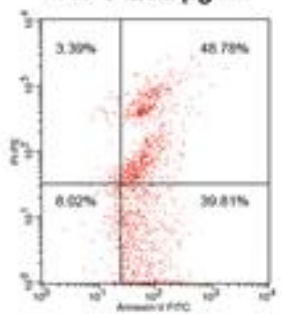

D

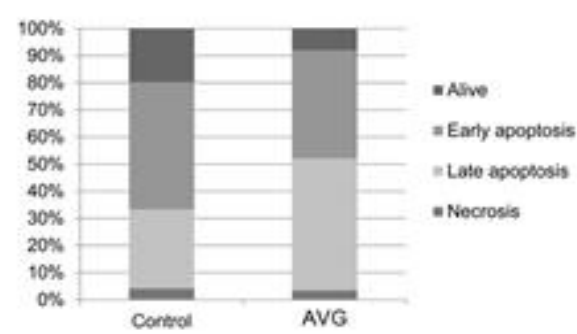

Figure 8.

Flow Cytometry of HCT116 cells treated with Annexin V-FITC/PI. The cells were maintained with the $\mathrm{IC}_{50}$ value of $150 \mu \mathrm{M} \mathrm{AE}(\mathrm{A})$ and $250 \mu \mathrm{g} / \mathrm{mL}$ AVG (C) for $72 \mathrm{~h}$, stained with FITC-annexin V/PI and analyzed by FACScan flow cytometer marked for apoptosis/necrosis

Q1: Annexin V negative/PI positive; Q2: Annexin V/PI positive; Q3: Annexin V positive/PI negative; Q4: Annexin V/PI negative. Control cells without the presence of AE and AVG. The analysis of data from flow Cytometry was performed using the FlowJo software. (B, D) Alive \%, early apoptosis \%, late apoptosis and necrosis \% were calculated comparing with treatment and 
A
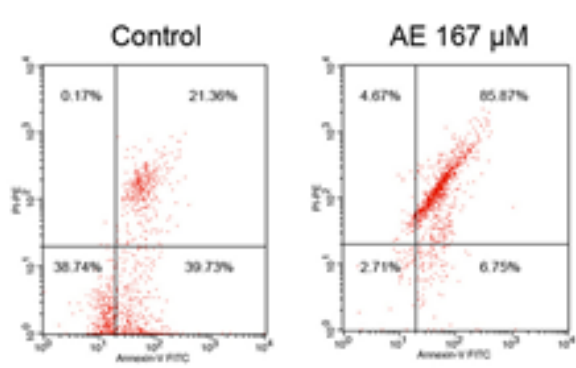

B

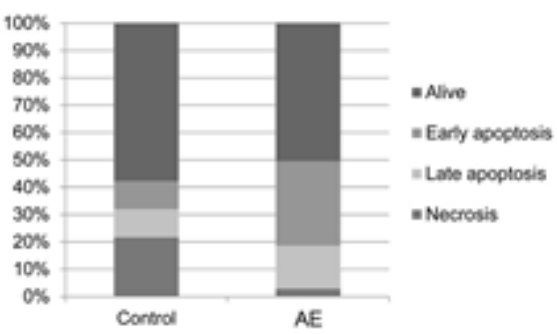

C
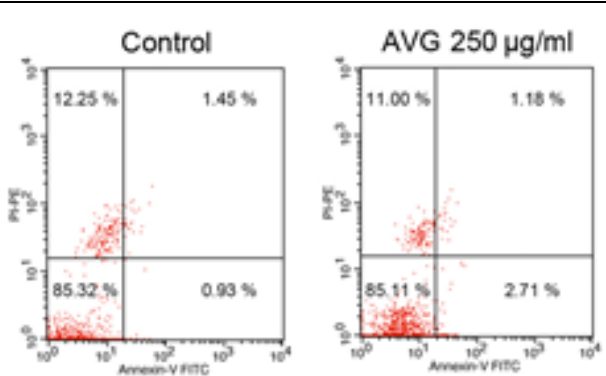

D

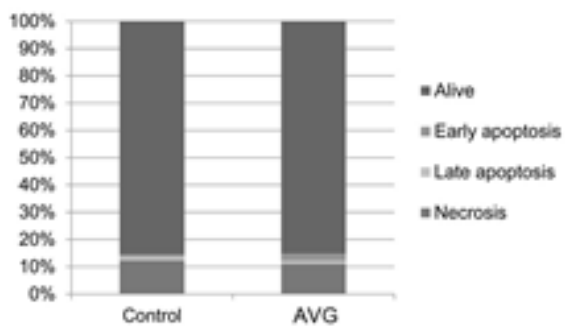

Figure 9.

Flow Cytometry of HEPG2 cells treated with Annexin V-FITC/PI. The cells were maintained with the $\mathrm{IC}_{50}$ value of $167 \mu \mathrm{M}$ AE (A) and $250 \mu \mathrm{g} / \mathrm{mL}$ AVG (C) for $72 \mathrm{~h}$, stained with FITC-annexin V/PI and analyzed by

FACScan flow cytometer marked for apoptosis/necrosis

Q1: Annexin V negative/PI positive; Q2: Annexin V/PI positive; Q3: Annexin V positive/PI negative; Q4: Annexin V/PI negative. Control cells without the presence of AE and AVG. The analysis of data from flow Cytometry was performed using the FlowJo software. (B, D) Alive \%, early apoptosis \%, late apoptosis and necrosis \% were calculated comparing with treatment and non-treatment groups

A

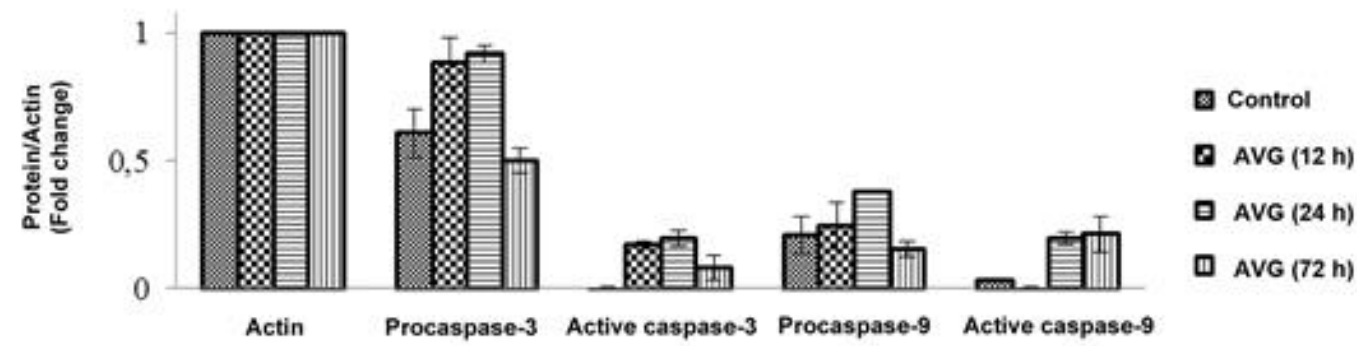

B

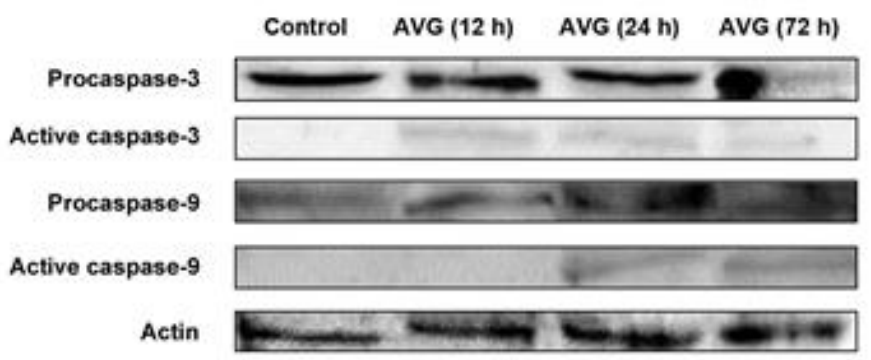

Figure 10.

Western blot analysis of caspase proteins expression levels after $250 \mu \mathrm{g} / \mathrm{mlAVG}$ treatment of HCT116 cells. Band intensity was analyzed by densitometry. Fold change of protein expression levels was calculated after bands were normalized to Actin

There are several data concerning the antitumour potential of A. vera extracts. Aloe species are cited between medicinal plants used as antitumour agents in Brazil [12]. Recent studies have demonstrated the in vivo anti-angiogenic effect of another species, Aloe arborescens on squamous-cell carcinoma and kidney tumours [17]. Several in vivo tests have been performed on different tumour cells and all of them gave positive results concerning antitumour activity of both $A$. vera gel and aloe extracts $[32,36]$. There is also one study 
undertaken on patients with colorectal cancer which have received 5-FU therapy alone and in combination with Aloe arborescens suggesting that the disease regressed significantly in the patients treated with Aloe alone [23]. The present study is the first to our knowledge undertaken in vitro on gastric, colon and hepatocellular cell cultures and comparing aqueous, methanolic leaf extracts, the gel extract and a purified substance from A. vera, AE.

$\mathrm{AE}$ is a hyrdoxyanthraquinone found in Aloe vera which antitumour [18, 20, 26] and anti-angiogenic [5] properties were studied in recent years. AE was found to have specific cytotoxic activity in vitro and in vivo on neuroectodermal tumours, but was ineffective on normal fibroblasts $[2,30]$. In a recent review, $\mathrm{AE}$ was presented as a new anti-cancer agent [42]. It has been shown that AE could be a potent anticancer agent for multiple tumour cells, suppressing their proliferation via $\mathrm{p} 53$ and its downstream $\mathrm{p} 21$ pathway and inducing in them cell cycle arrest and apoptosis [22]. Antitumour properties of $\mathrm{AE}$ isolated from $A$. vera leaves were evaluated against some different colon cancer lines (DLD-1 and HT-2) with $\mathrm{IC}_{50}$ values of 8.94 and $10.78 \mu \mathrm{M}$ respectively [14]. AE was assayed on HT29 human colon cancer cells in a study undertaken by Yuenyongsawad et al. and an $\mathrm{IC}_{50}$ value of $0.296 \pm$ $0.010 \mu \mathrm{g} / \mathrm{mL}$ was reported [43]. Contrarily to this finding in the present study, AE had no cytotoxic effect on HT-29 cells. The cytotoxic effect of AE on HCT 116 human colon cancer lines was evaluated in a study of Cui et al. with an $\mathrm{IC}_{50}$ value of $8.7 \mu \mathrm{M}$ [10]. Accordingly, in this study AE was also found cytotoxic for the same cell line with an $\mathrm{IC}_{50}$ value of $>150$ $\mu \mathrm{M}$. AE have been reported to exhibit cytotoxic effect on HEPG2 human hepatocellular carcinoma cells with an $\mathrm{IC}_{50}$ value of $10 \mu \mathrm{M}$ [10] whereas our study revealed a lower cytotoxicity of $\mathrm{AE}$ with an $\mathrm{IC}_{50}$ value of $166.97 \pm 5.41 \mu \mathrm{M}$ on HEPG 2 cells. The anticancer properties of $\mathrm{AE}$ were attributed primarily to its apoptotic effect [42]. Accordingly, in the present study AE has shown its cytotoxic effect by inducing apoptosis in AGS, HCT116 and HEPG2 cells.

Imatinib (IM) (imatinib mesylate, commercially available as Gleevec or Glivec, Novartis, Basel, Switzerland), is an inhibitor of certain tyrosine kinases and is used as a chemotherapeutic drug mostly in cancers like leukaemia. Nevertheless IM is also approved for gastrointestinal stromal tumours (GIST) [11]. IM was assayed on HCT116 cells at $10-50 \mu \mathrm{M}$ doses and $\mathrm{IC}_{50}$ of $21.2 \mu \mathrm{M}$ was reported after $72 \mathrm{~h}$ exposure [1]. In the present study, similar results with an $\mathrm{IC}_{50}$ of $50 \pm 2.60$ $\mu \mathrm{M}$ was found for IM on HCT116 cells after $72 \mathrm{~h}$ of exposure. However, no report on $\mathrm{IC}_{50}$ values of IM on AGS and HT-29 cells was found in the literature. In our study IM showed cytotoxic effect with an $\mathrm{IC}_{50}$ value of $65 \pm 1.31 \mu \mathrm{M}$ on AGS cells and of $56 \pm 1.37$ $\mu \mathrm{M}$ on HT-29 cells.
Fluorouracil (5-FU), a pyrimidine analogue, belongs to the family of drugs called antimetabolites and shows its cytotoxic effect by inhibiting irreversibly thymidylate synthase. 5-FU is commonly used in the chemotherapy of colorectal cancers and also as reference drug in cytotoxicity studies in cell cultures. Zhou et al. have reported $\mathrm{IC}_{50}$ values of $27.52 \pm 0.59 \mu \mathrm{M} / \mathrm{L}$ for $5-\mathrm{FU}$ on AGS cell lines [44]. In our study $\mathrm{IC}_{50}$ values of $>5$ $\mathrm{mg} / \mathrm{mL}$ was observed after $72 \mathrm{~h}$ of exposure. $\mathrm{IC}_{50}$ value of $2.3 \mathrm{~g} / \mathrm{mL}$ was reported for 5-FU on HT-29 colon cancer cells [31]. In our study, $\mathrm{IC}_{50}$ values of $>5 \mathrm{mg} /$ $\mathrm{mL}$ was observed for 5-FU on HT-29 cells. Literature survey revealed some studies undertaken on HCT116 colon cancer cell cultures for 5-FU with reported $\mathrm{IC}_{50}$ values of $33.17 \mu \mathrm{g} / \mathrm{mL}, 27.76 \mu \mathrm{M}$ and $6 \mu \mathrm{g} / \mathrm{mL}$, respectively [21, 33]. In our study, in accordance, with these studies a high $\mathrm{IC}_{50}$ of $0.4 \pm 0.03 \mathrm{mg} / \mathrm{mL}$ was found for 5-FU on the HCT116 colon cancer cell line. Ma et al. found an $\mathrm{IC}_{50}$ value of $46.83 \mu \mathrm{M}$ for 5 -FU on HEPG2 cells [24] whereas our finding was $0.47 \pm 0.02 \mathrm{mg} / \mathrm{mL}$ on the same cells.

In the present study, no significant difference was seen between the cytotoxic activities of the fresh leaves and dried leaves methanolic extracts. Therefore, we can suggest that there is no need to dry the leaves and that fresh leaves could be used as usual.

Nevertheless, no significant difference was also seen between fresh leaves aqueous and methanolic extracts in view of cytotoxicity. Only for AGS cells, the effect of $A$. vera fresh leaf skin and dried leaf skin methanolic extracts were better than AVG. Among the extracts assayed the best cytotoxic effect was seen with AVG on HCT116 colon cancer, whereas another hepato-cellular carcinoma cell line HEPG2, was resistant to Aloe extracts even at higher doses. This finding is contradictory with Du Plessis and Hamman [13], which reported an $\mathrm{IC}_{50}$ of 269.3 $\mathrm{mg} / \mathrm{mL}$ as even higher dose for $A$. vera gel effect on HEPG2 cells. The most important finding is that the extracts have shown very low or no cytotoxic activity towards HUVEC cells, similar to the reference drugs $\mathrm{AE}$ and 5-FU.

Another important finding is that no literature report for the apoptotic pathway of $A$. vera gel on HCT116 cells. In our present study, in time course experiments of $A$. vera gel in HCT116 to investigate apoptotic pathway, we have demonstrated that, for HCT116 cells, caspase- 3 activation was first initiated for it occurred as early as $12 \mathrm{~h}$ after AVG treatment, whereas caspase9 showed activation after $24 \mathrm{~h}$ (Figure 10).

\section{Conclusions}

As a conclusion we can assume that the selective cytotoxic and apoptotic effects exerted by $A$. vera gel and aloe emodin may represent an alternative cancer therapy. 


\section{Acknowledgement}

This work was supported by Istanbul University Scientific Research Projects. Project number: 28775.

\section{Conflict of interest}

The authors declare no conflict of interest.

\section{References}

1. Abdel-Aziz AK, Azab SSE, Youssef SS, El-Sayed AM, El-Demerdash E, Shouman S, Modulation of imatinib cytotoxicity by selenite in HCT116 colorectal cancer cells. Basic Clin Pharmacol Toxicol., 2015; 116(1): 37-46.

2. Ahirwar K, Jain SK, Aloe-emodin novel anticancer herbal drug. Phytomedicine, 2011; 3: 27-31.

3. Akev N, Can A, Sütlüpınar N, Çandöken E, Özsoy N, Yılmaz Özden T, Yanardağ R, Üzen E, Twenty years of research on Aloe vera. J Fac Pharm Istanbul, 2015; 45(2): 191-215.

4. Akev N, Turkay G, Can A, Gurel A, Yıldız F, Yardibi H, Ekiz EE, Uzun H, Effect of Aloe vera leaf pulp extract on Ehrlich ascites tumours in mice. Eur $J$ Cancer Prev., 2007; 16(2): 151-157.

5. Cárdenas C, Quesada AR, Medina MA, Evaluation of the anti-angiogenic effect of aloe-emodin. Cell Mol Life Sci., 2006; 63(24): 3083-3089.

6. Chandu AN, Kumar SC, Bhattacharjee C, Debnath S, Cytotoxicity study of plant Aloe vera (Linn). Chron Young Sci., 2012; 3(3): 233-235.

7. Chiu TH, Lai WW, Hsia TC, Yang JS, Lai TY, Wu PP, Ma CY, Yeh CC, Ho CC, Lu HF, Wood WG, Chung JG, Aloe-emodin induces cell death through Sphase arrest and caspase-dependent pathways in human tongue squamous cancer SCC-4 cells. Anticancer Res., 2009; 29(11): 4503-4511.

8. Choi S, Chung $\mathrm{MH}$, A review on the relationship between Aloe vera components and their biologic effects. Seminars Integrat Med., 2003; 1(1): 53-62.

9. Corsi MM, Bertelli AA, Gaja G, Fulgenzi A, Ferrero ME, The therapeutic potential of Aloe vera in tumorbearing rats. Int J Tissue React., 1998; 20(4): 115-118.

10. Cui XR, Takahashi K, Shimamura T, Koyanagi J, Komada F, Saito S, Preparation of 1,8-di-O-alkylaloeemodins and 15-amino-, 15-thiocyano-, and 15selenocyanochrysophanol derivatives from aloe-emodin and studying their cytotoxic effects. Chem Pharm Bull., 2008; 56(4): 497-503.

11. De Giorgi U, Verweij J, Imatinib and gastrointestinal stromal tumors: Where do we go from here?. Mol Cancer Ther., 2005; 4(3): 495-501.

12. De Melo JG, Santos AG, de Amorim ELC, do Nascimento SC, de Albuquerque UP, Medicinal plants used as antitumor agents in Brazil: an ethnobotanical approach. Evid Based Complement Alternat Med., 2011; 2011: 365359: 1-14.

13. Du Plessis LH, Hamman JH, In vitro evaluation of the cytotoxic and apoptogenic properties of aloe whole leaf and gel materials. Drug Chem Toxicol., 2014; 37(2): 169-177.

14. El-Shemy HA, Aboul-Soud MAM, Nassr-Allah AA, Aboul-Enein KM, Kabash A, Yagi A, Antitumor properties and modulation of antioxidant enzymes' activity by Aloe vera leaf active principles isolated via supercritical carbon dioxide extraction. Curr Med Chem., 2010; 17(2): 129-138.

15. Eshun $\mathrm{K}, \mathrm{He} \mathrm{Q}$, Aloe vera: a valuable ingredient for the food, pharmaceutical and cosmetic industries A review. Crit Rev Food Sci., 2004; 44(2): 91-96.

16. Im SA, Lee YR, Lee YH, Lee MK, Park YI, Lee S, Kim $\mathrm{K}$, Lee CK, In vivo evidence of the immunomodulatory activity of orally administered Aloe vera gel. Arch Pharm Res., 2010; 33(3): 451-456.

17. Kocik J, Balan BJ, Zdanowski R, Jung L, SkopińskaRózewska E, Skopiński P, Feeding mice with Aloe vera gel diminishes L-1 sarcoma-induced early neovascular response and tumor growth. Cent Eur J Immunol., 2014; 39(1): 14-18.

18. Kuo PL, Lin TC, Lin CC, The antiproliferative activity of aloe-emodin is through p-53-dependent and p-21dependent apoptotic pathway in human hepatoma cell lines. Life Sci., 2002; 71(16): 1879-1892.

19. Langmead L, Makins RJ, Rampton DS, Anti-inflammatory effects of Aloe vera gel in human colorectal mucosa in vitro. Aliment Pharmacol Ther., 2004; 19(5): 521-527.

20. Lee HZ, Lin CJ, Yang WH, Leung WC, Chang SP, Aloe-emodin induced DNA damage through generation of reactive oxygen species in human lung carcinoma cells. Cancer Lett., 2006; 239(1): 55-63.

21. Li F, Sun Q, Hong L, Li L, Wu Y, Xia M, Ikejima T, Peng Y, Song S, Daphnane-type diterpenes with inhibitory activities against human cancer cell lines from Daphne genkwa. Bioorg Med Chem Lett., 2013; 23(9): 2500-2504.

22. Lin JG, Chen GW, Li TM, Chouch ST, Tan TW, Chung $\mathrm{JG}$, Aloe-emodin induces apoptosis in T24 human bladder cancer cells through the p53 dependent apoptotic pathway. J Urol., 2006; 175(1): 343-347.

23. Lissoni P, Rovelli F, Brivio F, Zago R, Colciago M, Messina G, Mora A, Porro G, A randomized study of chemotherapy versus biochemotherapy with chemotherapy plus Aloe arborescens in patients with metastatic cancer. In Vivo, 2009; 23(1): 171-175.

24. Ma WF, Yang HK, Hu MJ, Li Q, Ma TZ, Zhou ZZ, Liu R, You WW, Zhao PL, One-pot synthesis and antiproliferative activity of novel 2,4-diaminopyrimidine derivatives bearing piperidine and piperazine moieties. Eur J Med Chem., 2014; 84: 127-134.

25. Mahbub AA, Le Maitre CL, Haywood-Small SL, McDougall GJ, Cross NA, Jordan-Mahy N, Differential effects of polyphenols on proliferation and apoptosis in human myeloid and lymphoid leukemia cell lines. Anticancer Ag Med Chem., 2013; 13(10): 1601-1613.

26. Mijatovic S, Maksimovic-Ivanic D, Radovic J, Popadic D, Momcilovic M, Harhaji L, Miljkovic D, Trajkovic $\mathrm{V}$, Aloe-emodin prevents cytokine-induced tumor cell death: the inhibition of auto-toxic nitric oxide release as a potential mechanism. Cell Mol Life Sci., 2004; 61: 1805-1815.

27. Mosmann T, Rapid colorimetric assay for cellular growth and survival: application to proliferation and cytotoxicity assays. J Immunol Methods, 1983; 65(12): 55-63.

28. Naveena, Bharath BK, Subramanian S, Antitumor activity of Aloe vera against Ehrlich ascites carcinoma (EAC) in Swiss albino mice. Int J Pharm Bio Sci., 2011; 2(2): 400-409. 
29. Nayak V, Gincy TB, Prakash M, Joshi J, Rao SS, Somayaji SN, Nelluri V, Bairy KL, Hepatoprotective activity of Aloe vera gel against paracetamol induced hepatotoxicity in albino rats. Asian J Pharm Clin Res., 2011; 1(2): 94-98.

30. Pecere T, Gazzola MV, Mucignat C, Parolin C, Vecchia FD, Cavaggioni A, Basso G, Diaspro A, Salvato B, Carli $\mathrm{M}$, Palù $\mathrm{G}$, Aloe-emodin is a new type of anticancer agent with selective activity against neuroectodermal tumors. Cancer Res., 2000; 60(11): 2800-2804.

31. Quispe-Mauricio A, Callacondo D, Rojas J, Zavala D, Posso M, Vaisberg A, Cytotoxic effect of Physalis peruviana in cell culture of colorectal and prostate cancer and chronic myeloid leukemia. Rev Gastroenterol Peru, 2009; 29(3): 239-246.

32. Saini MR, Goyal PK, Chaudhary, G, Anti-tumor activity of Aloe vera against DMBA/croton oil-induced skin papillomagenesis in Swiss albino mice. J Environ Pathol Toxicol Oncol., 2010; 29(2): 127-135.

33. Sharma SK, Kumar P, Narasimhan B, Ramasamy K, Mani V, Mishra RK, Majeed ABA, Synthesis, antimicrobial, anticancer evaluation and QSAR studies of 6-methyl-4-[1-(2-substituted-phenylamino-acetyl)1H-indol-3-yl]-2-oxo/thioxo-1,2,3,4-tetrahydro pyrimidine-5-carboxylic acid ethyl esters. Eur J Med Chem., 2012; 48: 16-25.

34. Shrestha A, Acharya A, Nagalakshmi NC, Aloe vera as traditional medicinal plant: a review on its active constituents, biological and therapeutic effects. World J Pharm Res., 2015; 4(6): 2146-2161.

35. Sicora O, Naghi MA, Soos I, Sicora C, The ethanolic stem extract of Caryopteris $X$ clandonensis posseses antiproliferative potential by blocking breast cancer cells in mitosis. Farmacia, 2019; 67(6): 1077-1082.

36. Skopiński P, Zdanowski R, Balan BJ, Siwicki AK, Kocik J, Lewicki S, Suska M, Pastwka K, Skopińska-
Rózewska E, Demkow U, Aloe arborescens and American cranberry (Vaccinium macrocarpon) extracts inhibit tumor-induced cutaneous angiogenesis in mice. Central Eur J of Immunol., 2013; 38(4): 480-485.

37. Strober W, Trypan blue exclusion test of cell viability. Curr Protoc Immunol., 2001; 111: A3.B.1-A3.B.3..

38. Tabolacci C, Lentini A, Mattioli P, Provenzano B, Oliverio S, Carlomosti F, Beninati S, Antitumor properties of aloe-emodin and induction of transglutaminase 2 activity in B16-F10 melanoma cells. Life Sci., 2010; 87(9-10): 316-324.

39. Tsuda H, Matsumoto K, Ito M, Hirono I, Kawai K, Beppu H, Fujita K, Nagao M, Inhibitory effect of Aloe arborescens Miller var. natalensis Berger (Kidachi aloe) on induction of preneoplastic focal lesions in the rat liver. Phytother Res., 1993; 7(7): S43-S47.

40. Vasincu A, Ababei DC, Miron A, Neamţu M, Vasincu IM, Charalambous C, Neophytou CM, Constantinou AI, Assessment of the potential antitumor effects of Glinus oppositifolius (L.) Aug. DC. extracts. Farmacia, 2019; 67(4): 656-661.

41. Winters WD, Benavides R, Clouse WJ, Effects of aloe extracts on human normal and tumor cells in vitro. Econ Bot., 1981; 35(1): 89-95.

42. Yordanova A, Koprinarova M, Is aloe-emodin a novel anti-cancer drug?. Trakia J Sci., 2014; 12 (Suppl 1): 92-95.

43. Yuenyongsawad S, Bunluepuech K, Wattanapiromsakul C, Tewtrakul S, Anti-cancer activity of compounds from Cassia garrettiana heartwood. Songklanakarin J Sci Technol., 2014; 36(2): 189-194.

44. Zhou T, Xiao C, Fan J, Chen S, Shen J, Wu W, Zhou $\mathrm{S}$, A nanogel of on-site tunable $\mathrm{pH}$-response for efficient anticancer drug delivery. Acta Biomater., 2013; 9(1): 4546-4557. 